\title{
Peningkatan Peran Riset Iptek dan Pendidikan Tinggi untuk Merespon Revolusi Industri 4.0
}

\author{
${ }^{1}$ Hary Soebagyo \\ 2Balai Besar Teknologi Kekuatan Struktur - Badan Pengkajian dan Penerapan Teknologi \\ Kawasan Puspiptek Serpong, Tangerang Selatan \\ hary.soebagyo@bppt.go.id*)
}

\begin{abstract}
Abstrak
Perkembangan dewasa ini menunjukkan semakin cepatnya perubahan dalam segala bidang kehidupan, semua itu diakibatkan efek globalisasi serta perkembangan teknologi informasi yang sangat akseleratif. Negara-negara dengan tingkat kapabilitas teknologi informasi yang tinggi akan memiliki daya inovasi dan daya saing yang sangat besar yang sanggup menentukan arah perkembangan ekonomi dalam skala global. Dengan kondisi internasional yang telah berubah sedemikian cepat dan dengan hadirnya revolusi industry 4.0 yang ditandai dengan adanya kemajuan teknologi Al (Artificial Intelegence), ICT (Information Communication Technology), loT (Internet of Things), Biotechnology dan Driverless Vehicles, maka sudah saatnya proses transformasi bangsa ini segera dapat direspon dan dilaksanakan melalui kebijakan strategis nasional dalam bidang iptek dan pendidikan tinggi. Hal pokok dalam mewujudkan Indonesia 4.0 adalah mempercepat pembangunan iptek nasional. Sementara itu pendidikan tinggi sebagai agen utama pembangunan iptek nasional dituntut kemampuannya untuk membudayakan rasa ingin tahu, budaya belajar yang tinggi dan memberikan apresiasi yang tinggi pada kegiatan riset iptek, serta kreatif dan inovatif dalam merespon kehadiran revolusi industry 4.0. Oleh karena itu peran riset iptek dan pendidikan tinggi harus segera ditingkatkan dengan kebijakan pengarusutamaan (mainstreaming) riset iptek nasional melalui perencanaan yang terintegrasi secara nyata dan konsisten dengan dunia industry.
\end{abstract}

Kata Kunci: riset; pendidikan tinggi; Indonesia 4.0, kebijakan strategis nasional, pengarusutamaan iptek, industri

\section{Pendahuluan}

\subsection{Riset dan Inovasi Sebagai Kunci Sukses}

Tak dapat dipungkiri lagi bahwa dampak globalisasi yang ada saat ini telah mempengaruhi segala sendi peri kehidupan masyarakat dunia. Terlebih lagi dengan kemajuan pesat dalam teknologi informasi dan komunikasi yang menyebabkan tata kelola dan perilaku berbangsa dan bernegara yang sudah sedemikian kompleks dan berbeda dari era sebelumnya. Bisnis dan ekonomi, politik, sosial budaya, serta tingkat kemakmuran bangsa juga berubah seiring perkembangan teknologi di era globalisasi ini.

Sementara itu, tingkat kemakmuran bangsa juga sangat tergantung dari daya saing yang dimilikinya. Daya saing bangsa itu sendiri juga tergantung pada perkembangan teknologi yang mereka kuasai. Bila dilihat dari data World Economic Forum (WEF) [10] tentang Human Development Index (HDI) menempatkan Indonesia di posisi 116 dari 189 negara yang disurvey. Sedangkan dari indeks daya saingnya, Indonesia berada di peringkat ke 45 dari 140 negara yang disurvey. Data itu juga menempatkan Amerika Serikat (AS) di urutan pertama dengan skor 85,6 dan selanjutnya diikuti oleh Singapura dengan skor 83,5 , berikutnya Jerman $(82,8)$, Swiss $(82,6)$ dan Jepang $(82,5)$. Sementara itu, untuk peringkat negara-negara ASEAN, setelah Singapura berada di peringkat atas, maka Malaysia berada di urutan kedua tertinggi dengan peringkat 25 dengan skor 74,5 . Berikutnya adalah Thailand di posisi 38 dengan skor 67,5 , diikuti Indonesia di urutan 45 dengan skor $(64,9)$. Selanjutnya, setelah itu adalah Filipina (56), Brunei Darussalam (62), Vietnam (77), Kamboja (110) dan Laos (122). Terdapat kekurangan dan kelemahan yang terjadi pada negara-negara berkembang, yaitu karena adanya kelemahan di sektor infrastruktur, kekurangan dalam penerapan teknologi informasi dan komunikasi, kurangnya pendidikan yang memadai, serta kekurangan dalam penguasaan teknologi dan inovasi. Bila dilihat dari indeks kemampuan pemanfatan teknologi (Technology Achievement Index) yang dibuat oleh UNDP, Indonesia berada pada urutan 60 dari 72 negara dengan nilai $T A I 0,211$. Selanjutnya jika dilihat dari data Global Innovation Index [11] yang dikeluarkan 
tahun 2018, Indonesia berada pada peringkat 85 dari 126 negara yang disurvey, dimana nomor 1 adalah Swis, berikutnya Belanda dan Swedia. Sementara itu ditingkat ASEAN peringkat berturutturut adalah Singapora (5), Malaysia (35), Thailand (44), Vietnam (45), Filipina (73) dan Indonesia berada diposisi (85).

Dari gambaran diatas, yaitu dari human development index (HDI) dan faktor daya saing, indeks teknologi dan juga indeks inovasinya, terlihat bahwa ilmu pengetahuan dan teknologi (Iptek) dan inovasi merupakan salah satu faktor penting yang menentukan daya saing bangsa di era global ini, Terlihat pula bahwa negara-negara dengan tingkat kapabilitas iptek dan inovasi yang tinggi negara-negara tersebut makmur dan mempunyai daya saing yang sangat besar serta menjadi leading dibanding negara-negara lain yang kemampuan iptek dan inovasinya lebih rendah. Negara-negara tersebut sukses memakmurkan rakyatnya berkat keunggulan iptek dan inovasinya sehingga masuk akal kalau disebutkan bahwa di era globalisasi saat ini iptek dan inovasi telah menjadi medan perang baru dari banyak bangsabangsa di dunia ini.

\subsection{Modal Sosial}

Banyak yang menyebutkan bahwa abad 21 ini sebagai jaman dimana masyarakat telah cukup banyak mempunyai pengetahuan, dimana pengetahuan akan menjadi kekuatan pokok untuk memenangkan percaturan global, terutama di bidang ekonomi dan bisnis. Sementara itu, akibat kemajuan teknologi di negara-negara maju, kini teknologi produksi telah mencapai tahapan yang tertinggi, mesin - mesin produksi berjalan secara efektif dan efisien sesuai dengan suatu standar tertentu yang sudah mapan. Yang dibutuhkan oleh mereka adalah penciptaan produk baru, dimana hal ini akan membutuhkan kreasi dan inovasi secara berkelanjutan. Kenyataanya, perubahan teknologi dan inovasi itu sebenarnya sangatlah kompleks, dimana harus melibatkan berbagai aktor seperti produsen-konsumen, berbagai unit bisnis seperti unit riset dan pengembangan dan pemasaran, dan berbagai jenis pengetahuan yang lain seperti organisasi dan manajemen. Sementara itu, kemajuan dalam penguasaan ilmu pengetahuan dan teknologi dapat dimanfaatkan untuk meningkatkan perkembangan ilmu pengetahuan dan teknologi melalui transfer pengetahuan di masyarakat. Hal ini penting bagi dunia pendidikan, terutama untuk pendidikan tinggi. Hal itu sangat jelas karena kemajuan pendidikan di Indonesia berhubungan erat dengan peradaban bangsa, yang pada gilirannya dapat berguna untuk mengatasi masalah sosial, budaya, ekonomi dan politik bangsa. Kini di era globalisasi, kekayaan sumber daya alam sudah bukan lagi merupakan suatu penentu keberhasilan suatu bangsa, namun penguasaan ilmu pengetahuan dan teknologi dan inovasi terbukti dapat memakmurkan bangsa itu sendiri. Oleh karenanya perlu segera secara sungguh-sungguh dalam membangun masyarakat dengan basis pengetahuan yang memadai untuk menghasilkan atau menciptakan suatu produk masyarakat yang berkemampuan dalam menguasai iptek dan inovasi.

Sementara itu, berkaitan dengan hal diatas, perlu pula disadari bahwa peran penting pendidikan tinggi atau universitas di Indonesia sangat mempengaruhi dan menjadi ujung tombak bagi pembangunan peradaban, meski pada proses penerapannya tidaklah mudah dalam menghadapi tantangan di era globalisasi. Perlu political will baik dari Pemerintah maupun legislative untuk peningkatan sarpras pendidikan, peningkatan kompetensi pendidik, memenuhi kebutuhan masyarakta dan industry, dan lain-lain.

Kini saatnya ada perubahan yang mendasar dengan mengeluarkan kebijakan-kebijakan yang sesuai kebutuhan. Pendidikan tinggi di era masyarakat berbasis pengetahuan harus digunakan untuk membangun keunggulan guna menopang produktivitas dan daya saing sebuah bangsa. Diharapkan perguruan tinggi dapat menjadi lebih unggul sesuai predikatnya masingmasing. Keungulan tersebut perlu tercermin di tiga bidang utama yang disebut tridarma perguruan tinggi, yaitu penelitian, pengajaran, pengabdian masyarakat. Tridarma perguruan tinggi tersebut tidak terlepas dari kegiatan riset Iptek dan inovasi karena itu adalah merupakan basis untuk kemajuan. Dengan demikian maka akan tercipta kemajuan dan perkembangan pendidikan tinggi yang lebih kreatif, inovatif dan berkelanjutan.

Selanjutnya, untuk menjadi lebih maju dan siap menghadapi era revolusi industry 4, mau atau tidak mau pendidikan di universitas perlu dilengkapi pula dengan apa yang disebut enterpreunership. Pendidikan di perguruan tinggi yang baik adalah yang lebih mengarah kepada riset, inovasi dan entrepreneurial. Dalam hal ini entrepreneurial di Indonesia harus bertumpu pada upaya penguatan manajemen, membangun jaringan dengan pasar secara luas, sumber pendanaan, stimulasi tradisi akademik dan integrasi tradisi enterepreneurial, serta membangun jaringan dengan universitas dan lembaga riset di luar negeri.

Masyarakat yang punya pengetahuan dasar dalam bidang iptek, inovasi dan enterpreunership ini merupakan modal social yang dibutuhkan untuk 
pembangunan nasional menuju negara maju dan makmur di masa mendatang.

\section{Riset Iptek, Pendidikan Tinggi dan Industri 4.0}

Sulit dibantah lagi bahwa peran riset iptek dan pendidikan tinggi sangat strategis dalam peningkatan daya saing dan menghadapi era revolusi industry 4.0. Untuk merespon dan memainkan peran strategis tersebut perlu meninjau permasalahan dan kendala serta bagaimana berstrategi untuk mewujudkan Indonesia 4.0 yang ditandai dengan target otomasi pada prioritas dalam 5 sektor/bidang strategis (Food \& Beverage, Textile \& Apperel, Automotive, Electronics, Chemical) [5].

\subsection{Pembangunan Iptek Nasional}

Beberapa permasalahan [3] yang terkait dengan pembangunan iptek dan pendidikan tinggi pada kondisi saat ini, yaitu lemahnya daya saing bangsa yang terkait dengan kemampuan iptek dapat ditunjukkan oleh sejumlah indikator yang harus diperhatikan, antara lain:

\section{Masih rendahnya kemampuan iptek nasional.}

Dalam indeks daya saing pertumbuhan, teknologi dan inovasi merupakan salah satu parameter utama selain parameter ekonomi makro, mikro dan institusi publik. Rendahnya kemampuan iptek nasional juga dapat dilihat dari jumlah paten penemuan baru dalam negeri serta masih rendahnya karya tulis ilmiah yang dipublikasikan di jurnal Internasional, meskipun akhir-akhir ini karya tulis tersebut sudah mulai menapak naik di level ASEAN.

Rendahnya kontribusi iptek nasional di sektor produksi. Hal ini antara lain ditunjukkan oleh kurangnya efisiensi dan rendahnya produktivitas, serta minimnya kandungan teknologi dalam kegiatan ekspor. TKDN dari hasil produksi masih harus didorong terus menerus melalui berbagia kebijakan.

Masih terbatasnya sumber daya iptek. Ini tercermin dari relatif rendahnya kualitas SDM dan kesenjangan tingkat pendidikan di bidang iptek. Jumlah insinyur dan doctor dalam bidang iptek masih perlu ditingkatkan terutama dalam bidangbidang yang menjadi misi dari Indonesia 4.0.

Belum berkembangnya budaya iptek di kalangan masyarakat. Budaya bangsa secara umum masih belum mencerminkan nilai-nilai iptek yang mempunyai penalaran obyektif, rasional, maju, unggul dan mandiri. Perlu ada upaya melalui diseminasi iptek ke masyarakat menggunakan kemampuan sarana ICT dan memanfaatkan portal yang ada baik di Pemerintah, Universitas maupun Dunia Usaha dan Industri.

Belum optimalnya peran iptek dalam mengatasi degradasi fungsi lingkungan hidup. Kemajuan iptek berakibat pula pada munculnya permasalahan lingkungan. Hal tersebut antara lain disebabkan oleh belum berkembangnya sistem manajemen dan teknologi pelestarian fungsi lingkungan hidup. Tentu masalah lingkungan hidup ini harus menjadi perhatian penting terutama untuk meningkatakan kesadaran masyarakat akan isu lingkungan yang telah menjadi isu global.

Masih lemahnya peran iptek dalam mengantisipasi dan menanggulangi bencana alam. Wilayah Indonesia dalam konteks ilmu kebumian global merupakan wilayah yang rawan bencana. Banyaknya korban akibat bencana alam merupakan indikator bahwa pembangunan Indonesia banyak yang belum berwawasan bencana. Kemampuan iptek nasional belum optimal dalam memberikan antisipasi dan solusi strategis terhadap berbagai permasalahan bencana alam seperti pemanasan global, anomali iklim, kebakaran hutan, banjir, longsor, gempa bumi dan tsunami. Riset untuk mitigasi bencana harus ditingkatkan dengan berbagai kebijakan terutama untuk peningkatan anggaran riset kebencanaan.

Sementara itu, selain hal yang telah disebutkan diatas, hal lain yang juga perlu dicermati adalah masalah budaya penelitian terutama riset dalam bidang iptek. Budaya penelitian sebagai pondasi kelembagaan riset iptek terkait erat dengan dunia pendidikan tinggi. Budaya dan rasa ingin tahu, budaya belajar dan apresiasi yang tinggi pada pencapaian ilmiah jangan sampai lemah dan terus menurun. Perlu solusi mengatasinya dan menggalakkan masyarakat gemar melakukan riset iptek.

Manajemen penelitian juga perlu menjadi perhatian mengingat hal ini sangat penting dalam penguatan dan eksistensi lembaga-lembaga penelitian dan pengembangan nasional. Lembaga penelitian telah banyak dilengkapi dengan sarana dan prasarana laboratorium, bahkan banyak yang berkualitas tinggi. Namun tidak menutup kemungkinan laboratorium ini akan gagal menjadi "rumah akademik" bagi peneliti, dosen ataupun mahasiswa, untuk mengenali beragam persoalan teknologi, persoalan masyarakat dan persoalan yang dihadapi industri. 
Sehubungan dengan pentingnya kualitas SDM, ilmu pengetahuan dan teknologi menjadi semakin lebih berperan, karena hanya dengan iptek semua perubahan yang terjadi dapat disikapi dengan tepat. Ini berarti menjadikan pendidikan memainkan salah satu peran penting dalam mempersiapkan SDM yang berkualitas dan kompetitif. Ketatnya kompetisi secara global khususnya dalam bidang ekonomi, telah menjadikan SDM yang berkualitas dengan penguasaan ilmu pengetahuan dan teknologi

\subsection{Industri 4.0}

Perkembangan iptek kedepan perlu dilihat untuk menjadi bahan acuan dalam perencanaan riset iptek nasional. Sementara Making Indonesia 4.0 dapat menjadi semangat dan untuk memicu perkembangan teknologi nasional dengan penetapan prioritas bidang yang harus dapat dicapai. Industri 4.0 adalah adalah sebuah kondisi pada abad ke-21 ketika terjadi perubahan besarbesaran di berbagai bidang lewat perpaduan teknologi yang mengurangi sekat-sekat antara dunia fisik, digital, dan biologi. Revolusi ini ditandai dengan kemajuan teknologi dalam berbagai bidang, khususnya kecerdasan buatan, robot, blockchain, teknologi

nano, komputer kuantum, bioteknologi, Internet of Things, percetakan 3D, dan kendaraan tanpa awak.

\section{5 sectors were selected for "Making Indonesia 4.0"}

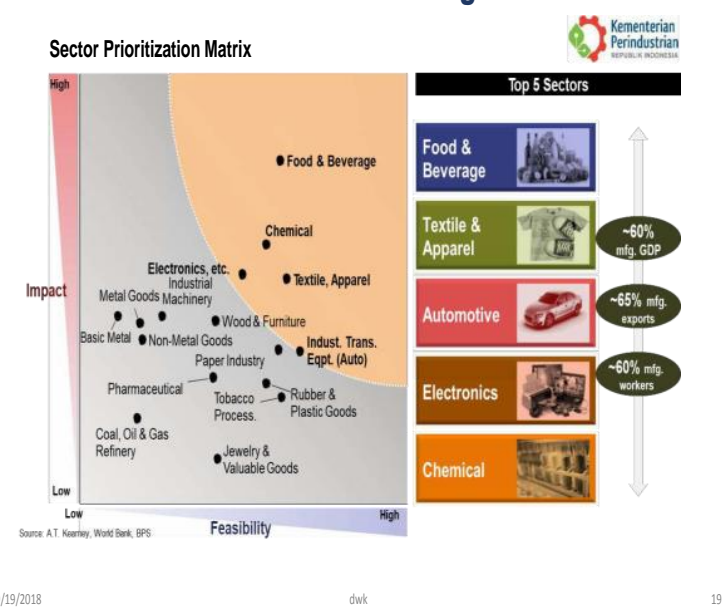

Gambar 1: Lima Bidang Prioritas Industri 4.0

Sebagaimana revolusi terdahulu, revolusi industri 4.0 berpotensi meningkatkan kualitas hidup masyarakat di seluruh dunia. Namun, kemajuan di bidang otomatisasi dan kecerdasan buatan telah menimbulkan kekhawatiran bahwa mesin-mesin itu suatu hari akan mengambil alih pekerjaan manusia. Selain itu, revolusi-revolusi sebelumnya masih dapat menghasilkan lapangan kerja baru untuk menggantikan pekerjaan yang diambil-alih oleh mesin, sementara kali ini kemajuan kecerdasan buatan dan otomatisasi dapat menggantikan tenaga kerja manusia secara keseluruhan.

Dengan kondisi internasional yang telah berubah sedemikian cepat dan dengan hadirnya revolusi industry 4.0 maka sudah saatnya proses transformasi bangsa ini untuk menjadi negara maju segera dapat direspon dan dilaksanakan melalui peningkatan dan penguaatan riset nasional dalam bidang iptek dan pendidikan tinggi yang selaras dengan semangat revolusi industri 4.0 tersebut. Pendidikan tinggi sebagai agen utama pembangunan iptek nasional dituntut kemampuannya untuk menggiatkan riset iptek dan mendorong kreatifitas serta membangun inovasi yang sesuai dengan bidang-bidang prioritas Indonesia 4.0. Gambar 1 menunjukkan 5 bidang yang menjadi prioritas pada "Making Indonesia 4.0".

Revolusi Industri 4.0 juga memberikan implikasi potensial terhadap dunia industry [5], antara lain:

- Robot Assisted production;

- Predictive Maintenance;

- $\quad$ Additive manufacturing of complex parts;

- Machines as a service;

- Big data drive quality control;

- Production line simulation;

- Smart supply network;

Sedangkan impaknya adalah:

1. Terhadap Individu: identitas, moral, etika dan hubungan kemanusiaan;.

2. Terhadap Kelompok masyarakat: inequality dan komunitasnya;

3. Terhadap Nasional/global: Pemerintah, propinsi, kabupaten dan kota, serta keamanan internasional

4. Terhadap Ekonomi: pertumbuhan, penuaan, produktifitas, pekerjaan, substitusi tenaga kerja, sifat pekerjaan

5. Terhadap Bisnis: ekspetasi konsumen, produk yang disempurnakan oleh data, inovasi kolaborasi, model dengan operasi yang baru.

Keterampilan atau skill SDM yang relevan dalam rangka menyongsong revolusi ndustry 4.0 akan banyak berubah sesuai dengan tuntutan perkembangan industry, dimana perubahan- 
perubahan tersebut menurut Forum Ekonomi Dunia diprediksi pada tahun 2020.

Sepuluh skill teratas [6] yang relevan dengan revolusi industri 4.0 adalah:
1. Complex Problem Solving
2. Critical Thinking
3. Creativity
4. People Management
5. Coordinating with Others
6. Emotional Intelligence
7. Judgment and Decision Making
8. Service Orientation
9. Negotiation
10. Cognitive Flexibility

Susunan atau building blocks dari industry 4.0 dapat dilihat pada gambar 2 .

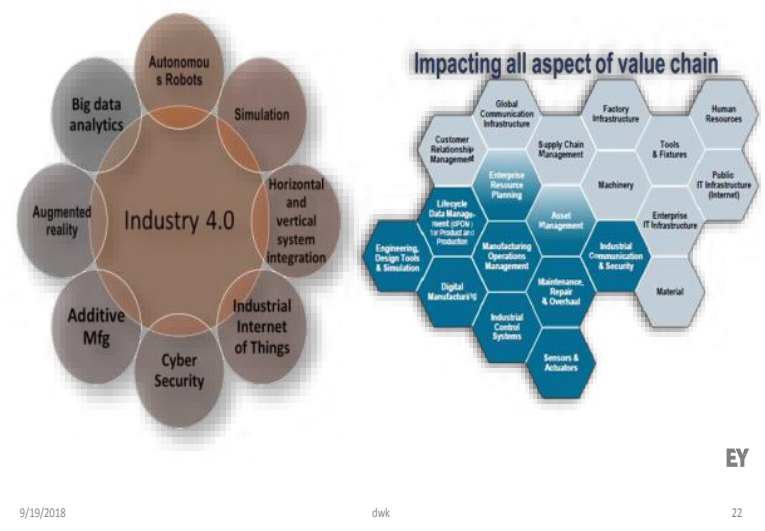

Gambar 2: Building blocks of Industry 4.0

\section{Menuju Indonesia 4.0}

Hadirnya revolusi industry 4.0 memberikan inspirasi Pemerintah untuk segera menetapkan "Making Indonesia 4.0". Untuk menanggapi kebijakan Indonesia 4.0 ini perlu pertimbangan pembuatan kebijakan yang kondusif unttuk mewujudkan dengan langkah-langkah strategis memposisikan riset iptek ddan inovasi serta pendidikan tinggi.

\subsection{Memposisikan Iptek Sebagai Politik Negara}

Pada saat ini, abad 21 sering didengungdengungkan sebagai era masyarakat berbasis pengetahuan (Knowledge Based Society/KBS), dimana pengetahuan akan menjadi sumber daya utama untuk memenangkan percaturan global, terutama di bidang ekonomi. Sementara itu, di akhir abad 20 yang lalu, telah terjadi pergeseran paradigma di bidang ekonomi, yaitu - dari
"Technology Based Economy (TBE)" menjadi “Knowledge Based Economy (KBE)"[3].

Politik pembangunan nasional selama ini amat tergantung pada kekayaan sumber alam, baik yang dapat diperbaharui, ataupun tidak. Akibatnya, pertumbuhan ekonomi ditumpukan pada sektor primer yaitu pertanian, kehutanan dan pertambangan yang nilai tambahnya rendah,

Industri pesawat terbang, industri kereta api, industri perkakas dan industri perkapalan nasional sebagai industri kreatif yang menghasilkan produkproduk padat teknologi dengan nilai tambah tinggi tidak memperoleh dukungan kebijakan industri yang memadai, terutama dalam mengembangan klaster industri yang berdaya saing tinggi.

Iklim yang tidak kondusif bagi kegiatan riset dan pengembangan (R\&D) dan kegiatan kreatif ini sekaligus merupakan sejenis "Ionceng kematian" bagi kelas kreatif seperti para peneliti dan perekayasa, insinyur, arsitek, artis dan para profesional lainnya.

3.2 Pengarusutamaan Riset dan Pendidikan Tinggi Meski kegiatan riset sudah lama dilakukan baik di lembaga-lembaga riset Pemerintah dan universitas, bahkan berbagai lembaga atau organisasi keilmuan juga sudah dibentuk sejak lama, namun potret riset iptek masih saja belum menampakkan sebagaimana diharapkan oleh masyarakat. Kontribusi dan peran mereka masih menjadi pertanyaan bagi masyarakat terutama kontribusinya terhadap perekonomian nasional. Riset dan pengembangan yang dilakukan oleh lembaga riset dan universitas belum banyak yang berorientasi pada kebutuhan masyarakat. Umumnya riset lebih banyak dilakukan menurut keinginan para penelitinya. Riset-riset yang dilakukan terkadang bersifat parsial dan kurang dilakukan secara menyeluruh untuk menyelesaikan suatu masalah yang besar dan yang lebih berdampak bagi masyarakat.

Sementara itu, perguruan tinggi yang diharapkan menjadi sebuah pusat keunggulan (centre of excellence) belum focus pada riset-riset besar yang berdampak nasional. Umumnya riset yang dilakukan adalah riset untuk penguatan SDM atau riset yang dilakukan untuk penguatan keilmuan. Tri Dharma Perguruan Tinggi belum mengedepankan riset namun lebih banyak porsinya untuk kegiatan pengajaran.

Sinyal lemah inilah yang ditangkap oleh industri sebagai ketidaksiapan lembaga riset dan universitas dalam mendukung secara nyata dalam kegiatan industri. Namun dalam konteks pengembangan SINas (Sistem Inovasi Nasional), 
masih adanya kesenjangan ini juga dikarenakan masih belum tumbuhnya lembaga intermediasi yang menjadi "jembatan penghubung" antara pegiat riset dengan industri dan dunia usaha sebagai penggunanya.

Perguruan tinggi di Indonesia, bahkan yang terbaik sekalipun, masih belum menjadikan riset sebagai mesin kedua yang sama pentingnya setelah mesin pertama pendidikan, mainstreaming riset masih belum diputuskan oleh universitas - universitas tersebut. Seharusnya, perguruan-perguruan tinggi ini menetapkan sebuah Program Utama Riset Universitas yang dirumuskan bersama-sama dengan para stakeholders penelitian

Melihat kondisi kegiatan riset di lembaga-lembaga riset dan universitas saat ini, alangkah baiknya bila segera dilakukan terobosan dalam rangka Making Indonesia 4.0 dengan melakukan pengarusutamaan riset iptek dengan melakukan integrasi kegiatan riset di universitas dengan industri.

\section{Diskusi}

Dari uraian diatas yang memperhitungkan hal tentang kondisi dan iklim riset iptek saat ini dan kesiapan perguruan tinggi menanggapi perubahan situasi global dengan hadirnya revolusi industry 4.0 maka ada beberapa hal yang dapat menjadi perhatian kita guna merespon perkembangan tersebut dan mewujudkan Indonesia 4.0, yaitu:

1. Menyusun paket kebijakan untuk menjadikan iptek sebagai bagian dari politik negara melalui pengarusutamaan sinergi dan integrasi riset dan inovasi dari lembaga riset Pemerintah, Perguruan Tinggi, Industri;

2. Membangun strategi difusi dan diseminasi konten iptek dan materi pendidikan yang berpijak pada kekuatan bangsa dan sesuai bidang prioritas Indonesia 4.0 melalui media ICT terkini yang dapat diakses langsung oleh lapisan masyarakat (industry, siswa dan mahasiswa ataupun umum). Diseminasi dengan konten seperti diatas dapat dilakukan melalui portal yg ada saat ini dan diperkuat pula dengan penugasan ke lembaga-lembaga pendidikan, jalur Pemerintah dan organisasi sosial kemasyarakatan.

3. Mendorong peningkatan kegiatan riset iptek di perguruan tinggi, mensinergikan dan mengintegrasikan kegiatan risetnya dengan klaster industri;

4. Mendorong sektor industri untuk melakukan inovasi sesuai misi dan semangat Indonesia 4.0 dengan memberikan stimulus dari Pemerintah berupa tax incentive dan research funding bila mereka bekerjasama dengan universitas dan lembaga-lembaga riset.

5. Mendorong pengembangan industri kreatif serta mendorong tumbuhnya lembaga intermediasi yang dapat menjadi jembatan penghubung antara periset dengan industry sebagai pengguna hasil risetnya.

\section{Ucapan Terima Kasih}

Ucapan terima-kasih kami sampaikan kepada Pimpinan Balai Besar Teknologi Kekuatan Struktur - BPPT yang telah memberi kesempatan dan membantu akomodasi keikutsertaan pada Seminar Nasional Instrumentasi, Kontrol dan Otomasi (SNIKO) 2018 di Bandung.

\section{Daftar Pustaka}

[1] Kementerian Riset dan Teknologi, Undangundang Undang-Undang Nomor 18 Tahun 2002 tentang Sistem Nasional Penelitian, Pengembangan, dan Penerapan IImu Pengetahuan dan Teknologi, Jakarta, 2002.

[2] Kementerian Riset dan Teknologi, Buku Putih Penelitian Pengembangan Penerapan Iptek 2005 - 2005, Jakarta, 2006;

[3] Kementerian Riset dan Teknologi, Jakstranas Pembangunan Nasional Iptek 2010 - 2014, Jakarta, 2010;

[4] Kementerian Riset, Teknologi dan Pendidikan Tinggi, Rencana Induk Riset Nasional (RIRN), Perpres Nomor 38 Tahun 2018, Jakarta, 2018.

[5] Kementerian Perindustrian, Making Indonesia 4.0, Jakarta, 2018.

[6] Djoko W. Karmiadji, Orasi IImiah Dies Natalis 36 Polsri Palembang, September 2018.

[7] Robert R. Schaller, Technology Roadmap : Implications for Innovation, Strategy, and Policy, The Institute of Public Policy, George Mason University Fairfax, VA, 26 March 1999.

[8] Schwartz, Peter. The Art of The Long View for Large Organization, Moscow, October 2011.

[9] William N Dunn, Pengantar Analisis Kebijakan Publik, Gadjah Mada University Press, Yogyakarta, 1998. 
Seminar Nasional Instrumentasi, Kontrol dan Otomasi (SNIKO) 2018

Bandung, Indonesia, 10-11 Desember 2018

[10]World Economic Forum (WEF), The Global Competitiveness Report 2017-2018, ISBN13: 978-1-944835-11-8, 2017;

[11]World Intellectual Property Organization (WIPO), Global Innovation Index 2018: Energizing The World With Innovation, ISBN 979-10-95870-09-8, 2018. 